\title{
Effects of drying methods on compositional characterization and functional characteristics of Blighia sapida aril oil ${ }^{\text {th }}$
}

\author{
Olarewaju M. Oluba ${ }^{1, *}$, Divine-Favour O. Mbamara ${ }^{1}$, Oghenerobor B. Akpor ${ }^{2}$, Feyikemi D. Adebiyi ${ }^{3}$, \\ Olayinka O. Alabi ${ }^{4}$, Ayoola Shoyombo ${ }^{4}$ and Omorefosa O. Osemwegie ${ }^{2}$ \\ ${ }^{1}$ Department of Biochemistry, Food Safety Toxicology Research Unit, College of Pure Applied Sciences, Landmark University, Omu- \\ Aran, Kwara State, Nigeria \\ ${ }^{2}$ Department of Microbiology, College of Pure \& Applied Sciences, Landmark University, Omu-Aran, Kwara State, Nigeria \\ 3 Department of Chemical Sciences, Joseph Ayo Babalola University, Ikeji-Arakeji, Osun State, Nigeria \\ ${ }^{4}$ Department of Animal Science, College of Agricultural Sciences, Landmark University, Omu-Aran, Kwara State, Nigeria
}

Received 21 July 2020 - Accepted 2 November 2020

\begin{abstract}
The composition of Blighia sapida fruits is reported to differ based on its origin, variety, and preservation technique. In this study, the effect of drying method on the composition as well as the antioxidant activity of oven-dried and sun-dried B. sapida aril flour and oil were examined using standard procedures. Sun-dried B. sapida aril flour had significantly higher protein and fat content compared to the oven-dried flour. In addition, sun-dried $B$. sapida aril flour contained a more diverse phytochemical profile compared to the oven-dried flour. However, oven-dried B. sapida aril oil (ODAO) showed a higher percentage of unsaturated fatty acids compared to oil from the sun-dried B. sapida flour (SDAO). On the other hand, SDAO showed significantly higher DPPH scavenging and nitric oxide inhibitory activities compared to ODAO. Based on these findings, sun-drying is recommended for both nutritional purposes and other health-promoting usage such as antioxidant, over oven-drying.
\end{abstract}

Keywords: Blighia sapida aril flour / Blighia sapida aril oil / food composition / fatty acid profile / antioxidants

\begin{abstract}
Résumé - Effets des méthodes de séchage sur la caractérisation de la composition et les caractéristiques fonctionnelles de l'huile de Blighia sapida aril. La composition des fruits de Blighia sapida diffère selon leur origine, leur variété et leur technique de conservation. Dans cette étude, l'effet de la méthode de séchage sur la composition ainsi que l'activité antioxydante de la farine et de l'huile de $B$. sapida aril séchées au four et au soleil sont examinés selon des procédures standard. La farine de B. sapida aril séchée au soleil avait une teneur en protéines et en graisses nettement plus élevée que la farine séchée au four. Toutefois, la farine de $B$. sapida aril séchée au four présente un profil phytochimique plus diversifié que celle séchée au soleil. L'huile de $B$. sapida aril séchée au four (ODAO) présentait un pourcentage plus élevé d'acides gras insaturés que celle séchée au soleil (SDAO). En outre, l'ODAO a montré des activités de piégeage du DPPH et d'inhibition de l'oxyde nitrique significativement plus élevées que la SDAO. Sur la base de ces résultats, le séchage au soleil pourrait être plus adapté à des fins nutritionnelles, alors que pour d'autres usages favorables à la santé, tels que les antioxydants, le séchage au four semblerait plus approprié.
\end{abstract}

Mots clés : Farine de Blighia sapida aril / huile de Blighia sapida aril / composition des aliments / profil des acides gras / antioxydants

\section{Introduction}

The challenge of food security, coupled with increasing global population, has necessitated the search for additional

\footnotetext{
Contribution to the Topical Issue "Minor oils from atypical plant sources / Huiles mineures de sources végétales atypiques".

*Correspondence: oluba. olarewaju@lmu.edu.ng;

olubamike2000@yahoo.co.uk
}

sources of nutrients. Nigeria, and indeed, all of Africa, has a rich diversity of plant food sources which have been grossly underutilized. From time immemorial, fruits and vegetables have played significant roles in meeting the nutritional needs of animals and humans, thus improving global nutrition and wellness (Gul et al., 2016). Plant fruits constitute a rich source of the macro and micronutrients required for animal growth and development (Saxena et al., 2013). Thus, the exploration and evaluation of the nutritional potential of indigenous wild 
fruits and vegetables will not only reduce hunger but also improve global nutrition and wellness.

Blighia sapida is an herbaceous perennial plant native to tropical West and Central Africa. It is a member of the Sapidaceae family. In Nigeria and Jamaica, where B. sapida fruit forms a major delicacy, it is commonly called ackee. Ackee apple is consumed not only for nutrition but also for disease prevention (Adarkwa-Yiadom, 2018; Lawal et al., 2018). The potential of ackee apple to promote health and wellbeing has led to a recent increase in research on this grossly underused plant, especially in Nigeria and neighboring West African states where ackee is a staple food. In Jamaica, however, the ackee industry contributed a significant US $\$ 400$ million in revenue in 2005 (Ekué et al., 2011). Thus, ackee has great economic potential in countries like Nigeria, especially with the recent push to open the non-oil sector. Ackee fruit is consumed both fresh and cooked. In addition, products such as soap made from ackee provide substantial revenue to peasant farmers, especially women (Ekué et al., 2010; Adeduntan et al., 2016).

Immature ackee fruit can be somewhat toxic. Symptoms such as vomiting, drowsiness and even hyperglycemia have been reported due to acute toxic effects associated with the consumption of unripe ackee aril fruit (Manchester, 1974). In addition, there has been reported cases of coma and death occurring within $12 \mathrm{~h}$ in severe cases of immature ackee aril poisoning (Brown et al., 1991). This is due to the presence of hypoglycin A, an unusual amino acid (Bowen-Forbes and Minott, 2011). However, as the ackee fruit matures, its hypoglycin $\mathrm{A}$ is converted to a less toxic hypoglycin $\mathrm{B}$. In addition, proper harvesting and processing techniques, such as cooking of the mature fruit, have also been shown to reduce the hypoglycin level in the fruit by leaching hypoglycin A (Golden et al., 1984; Blake et al., 2006).

Antioxidants are substances that impede the oxidation of biomolecules either by extinguishing free radicals or chelating the metals (Arina and Harisun, 2019). Antioxidants protect against the deleterious effects of free radicals. They also neutralize the adverse effects of oxidative stress (Asadi et al., 2017). Polyphenols found in both edible and non-edible plants have been found to have antioxidant activity (Hoba et al., 2018). This is mainly due to their ability to scavenge and neutralize the various forms of free radicals. B. sapida aril has been demonstrated to have as much as $15 \%(\mathrm{w} / \mathrm{w})$ oil content. Thus, B. sapida fruit could be properly classified as an oilbearing fruit with a rich content of both saturated and unsaturated fatty acids (Hoba et al., 2018).

Drying as a preservation technique is most often employed in the dehydration of food, thus reducing its susceptibility to microbial spoilage. This specific method of preservation has been shown to affect the quality of food, including its physicochemical and sensorial properties as well as microbiological attributes. The use of drying methods, such as sun drying and oven drying, in the dehydration of $B$. sapida arils has been reported by some authors (Akintayo et al., 2002; Oyeleke et al., 2013), and the effect of different drying methods on other agricultural products has been widely reported by several others. However, there exists a dearth of information on the effects of different drying techniques on the nutritional quality of dried B. sapida arils. The present study was therefore designed to provide information on the comparative effects of sun- and oven- drying methods in the preservation of B. sapida aril on the composition of its flour as well as the nutritional and antioxidant properties of its oil extract.

\section{Materials and methods}

\subsection{Chemical and reagents}

All chemicals and reagents were of analytical grade and were products of Sigma-Adrich (UK) unless otherwise stated.

\subsection{Plant material}

Fresh B. sapida fruits were harvested in the month of August from an ackee apple plant at Ikare Akoko, Ondo State, Nigeria. The arils were immediately removed from the pods, seeds and raphe of the fruits; washed with copious water and transported in dark cellophane bags to the laboratory for further analysis. The leaves and fruits of the plant sample were taken to the Department of Plant Science, University of Ilorin (Nigeria) for authentication.

The ackee apple arils were divided into two equal halves. A portion was dried in the sun for five consecutive days $(120 \mathrm{~h})$ at $33^{\circ} \mathrm{C}$ (Ayanwale et al., 2007) and labelled sun-dried apple aril (SDA). The second portion was dried in an oven (Gallenkamp OV-300, England) at $50{ }^{\circ} \mathrm{C}$ for $48 \mathrm{~h}$.

\subsection{Oil extraction}

The sun-dried and oven-dried B. sapida arils were separately milled into fine powder using a kitchen blender and the powdered samples kept separately in an airtight dark container and kept at $4{ }^{\circ} \mathrm{C}$ until required for further analysis. A known sample $(50 \mathrm{~g})$ of each powder was extracted with $\mathrm{n}$ hexane (1:5; flour:solvent) at $65-68^{\circ} \mathrm{C}$ for $6 \mathrm{~h}$ using a Soxhlet apparatus (Karthikeyan et al., 2017). The extracted oil was dried using a rotary evaporator and then stored in a dark airtight container. The percentage oil yield was calculated using the equation below:

$$
\text { Percentageyield }=\frac{W_{1}}{W_{2}} \times 100,
$$

Where $W_{1}$ is the weight of the oil and $W_{2}$ the weight of the dried B. sapida flour sample.

\subsection{Proximate composition}

The proximate composition of the fresh and defatted ovendried and sun-dried B. sapida aril flours was determined using AOAC methods (2005).

\subsection{GC-MS analysis}

Samples of both fresh and defatted B. sapida aril flour were each separately pulverized and mixed with GC-grade methanol $(1: 5 \mathrm{w} / \mathrm{v})$. The mixture was placed in an orbital shaker and left at $25 \pm 2{ }^{\circ} \mathrm{C}$ for $48 \mathrm{~h}$. Thereafter, the mixture was filtered through a muslin cloth to obtain the crude extract which was concentrated using a rotary evaporator and stored at $-4{ }^{\circ} \mathrm{C}$ 
Table 1. Proximate composition analysis of both fresh and defatted oven-dried and sun-dried B. sapida aril flours.

\begin{tabular}{|c|c|c|c|c|}
\hline Composition (\%) & \multicolumn{2}{|c|}{ Oven-dried aril flour } & \multicolumn{2}{|c|}{ Sun-dried aril flour } \\
\hline Crude protein & $15.03 \pm 1.13^{\mathrm{a}}$ & $19.50 \pm 2.21^{\mathrm{b}}$ & $21.88 \pm 1.58^{\mathrm{b}}$ & $26.40 \pm 3.80^{\mathrm{c}}$ \\
\hline Crude fibre & $5.53 \pm 0.55^{\mathrm{a}}$ & $8.60 \pm 0.55^{b}$ & $5.22 \pm 0.95^{\mathrm{a}}$ & $8.33 \pm 1.11^{\mathrm{b}}$ \\
\hline Ash & $8.12 \pm 0.88^{\mathrm{b}}$ & $8.33 \pm 1.22^{\mathrm{b}}$ & $6.03 \pm 1.10^{\mathrm{a}}$ & $6.10 \pm 0.53^{\mathrm{a}}$ \\
\hline
\end{tabular}

Results are means \pm SD of three determinations. Values in the same row carrying different alphabets are significant $(p>0.05)$.

until required for further analysis. The methanol extract of both defatted flour for both sun-dried and over-dried B. sapida aril were each separately subjected to GC-MS analysis in order to identify its constituent bioactive metabolites. The detection was at $70 \mathrm{eV}$ ionization energy and $60 \mathrm{kPa}$ with helium as the carrier gas. The initial temperature of the oven was set at $100{ }^{\circ} \mathrm{C}$ for $2 \mathrm{~min}$ and ramp rate of $4^{\circ} \mathrm{C}$ per min to $225^{\circ} \mathrm{C}$ and then $1{ }^{\circ} \mathrm{C}$ per min to $245^{\circ} \mathrm{C}$ followed by 40 to $280^{\circ} \mathrm{C}$ with a $30 \mathrm{~min}$ hold. An injection volume of $2 \mu \mathrm{L}$ was injected at $280{ }^{\circ} \mathrm{C}$ with a split ratio of 1:50. Detected spectra were identified from the NIST database using the ChemStation software. Following the extraction process prior to GC-MS analysis, the extract was derivatized with $\mathrm{N}, \mathrm{O}$-bis(trimethylsilyl) trifluoroacetamide (BSTFA) and trimethylchlorosilane (TMCS) reagents. The resulting trimethylsilyl derivatives were separated and quantified using GC-MS (Stalikas, 2007).

\subsection{Fatty acid analysis}

The fatty acid profile of the B. sapida aril oil was determined using gas chromatography as described by Oluba et al. (2008).

\subsubsection{Physicochemical properties}

The refractive index and specific gravity of the oil samples were determined using a refractometer and a universal hydrometer respectively. The iodine value was evaluated according to the procedure described by Strong and Kosh (1974). Acid and peroxide values were estimated following the methods of Li et al. (2007) and Yildiz et al. (2003), respectively while the saponification number was evaluated based on the method of Dileesh et al. (2013). The free fatty acid content of the oil samples was determined using the titrimetric method of Kardash and Tur (2005) using phenolphthalein as indicator.

\subsection{Total phenolic content determination}

Total phenol content of the oil samples was determined as reported by Waterhouse (2002) and its content was calculated and recorded as gallic acid equivalent (GAE).

\subsection{Antioxidant analysis}

\subsubsection{DPPH scavenging activity}

The DPPH scavenging activity of the oil sample was carried out following the procedures of Bersuder et al. (1998) as described by Oluba et al. (2020). The DPPH scavenging capacity was estimated according to the equation:

$$
\% \text { Inhibition }=\frac{A_{\text {control }}-A_{\text {sample }}}{A_{\text {control }}} \times 100,
$$

- $\mathrm{A}_{\text {control }}=$ Absorbance of the ethanolic DPPH solution;

- $\mathrm{A}_{\text {sample }}=$ Absorbance of oil sample or vitamin $\mathrm{C}$ in ethanolic DPPH solution.

The sample concentration required to scavenge $50 \% \mathrm{DPPH}$ radical was evaluated from the vitamin $\mathrm{C}$ standard curve.

\subsubsection{Nitric oxide scavenging activity}

The oil samples were evaluated for their potential to scavenge nitric oxide according to the procedure detailed by Makhija et al. (2011). The procedure is based on the generation of nitric oxide radical $\left(\mathrm{NO}^{*}\right)$ due to the decomposition of sodium nitroprusside in aqueous solution at $\mathrm{pH}$ 7.2. The $\mathrm{NO}^{*}$ then reacts with oxygen to form nitrite and nitrate whose concentration is determined using Griess's reagent (2008).

\subsubsection{Lipid peroxidation}

The scavenging activity of the oil samples against lipid peroxides (herein measured as thiobarbituric acid reactive species, TBARS) generated by ferric sulphate in egg yolk homogenate was assayed using the method described by Okoh et al. (2014). Briefly, $0.1 \mathrm{~mL}$ of varying concentration $(0.05$ to $0.5 \mathrm{~mL}$ ) of the oil sample or vitamin C dissolved in DMSO as the case may be, was added to $0.5 \mathrm{~mL}$ of egg yolk homogenate $(10 \%)$ and the resulting mixture made up to $1.0 \mathrm{~mL}$. Lipid peroxidation was then induced by the addition of $0.5 \mathrm{~mL}$ ferric sulphate $(0.07 \mathrm{M})$. The mixture was incubated for $30 \mathrm{~min}$ and $1.5 \mathrm{~mL}$ each of $10 \%$ acetic acid ( $\mathrm{pH} \mathrm{3.5)}$ and $0.08 \%$ 2-thiobarbituric acid (in $1.1 \%$ sodium dodecyl sulphate and $20 \%$ trichloroacetic acid) was added. The reaction mixture was vortexed for $5 \mathrm{~min}$, heated at $65^{\circ} \mathrm{C}$ for one hour and then allowed to cool. To the cooled solution, $0.5 \mathrm{~mL}$ of $\mathrm{n}$-butanol was added and the resulting mixture centrifuged at $3000 \mathrm{rpm}$ for $10 \mathrm{~min}$. The absorbance of the upper organic layer was read at $532 \mathrm{~nm}$.

\subsection{Statistical analysis}

Results are reported as mean $\pm \mathrm{SD}$ and statistically analyzed using One-Way Analysis of Variance (ANOVA) 
(a)

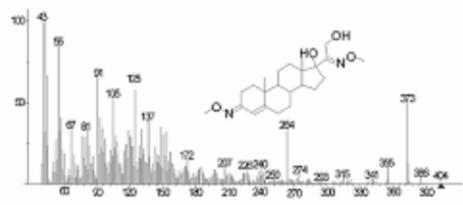

(x)

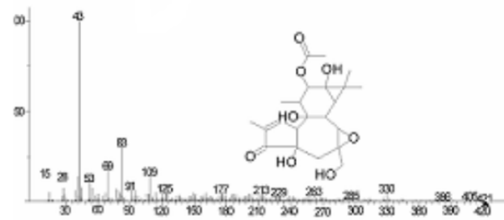

(b)

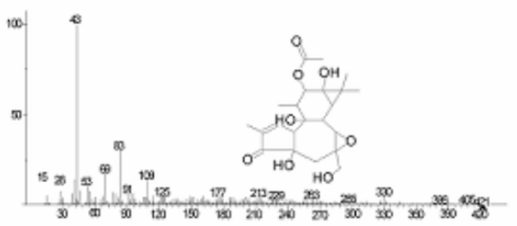

(y)



(w)

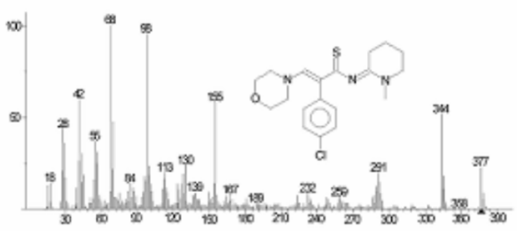

(z)

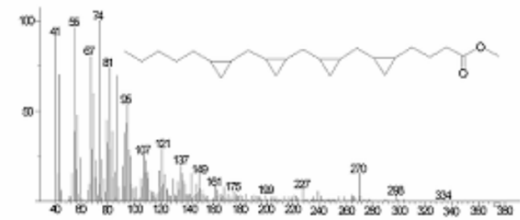

Fig. 1a. Pahytochemical contituents of fresh oven-dried ( $\mathrm{a}$ and $\mathrm{b}$ ) and sun-dried (w, $\mathrm{x}, \mathrm{y}$ and $\mathrm{z}$ ) B. sapida aril flour as determined using GC-MS analysis. Note: a: Pregn-4-ene-3,20-dione,17,21-dihydroxy-, bis(O-methyloxime); b: 4H-Cyclopropa[5',6']benz[1',2':7,8] azuleno[5,6-b]oxiren-4-one, 8-(acetyloxy)-1,1a,1b,1c,2a,3,3a,6a,6b,7,8,8a-dodecahydro-3a,6b,8a-trihydroxy-2a-(hydroxymethyl)-1,1,5,7-tetramethyl-, (1a $\alpha, 1 \mathrm{~b} \beta, 1 \mathrm{c} \beta, 2 \mathrm{a} \beta, 3 \mathrm{a} \beta, 6 \mathrm{a} \alpha, 6 \mathrm{~b} \alpha, 7 \alpha, 8 \beta, 8 \mathrm{a} \alpha)-; \mathrm{w}$ : N-Methylpiperidin-2-yliden-3-morpholino-2-(4-chlorphenyl)-thioacrylamide; x: 4H-Cyclopropa[5',6']benz[1',2':7,8]azuleno[5,6-b]oxiren-4-one,8 (acetyloxy)1,1a,1b,1c,2a,3,3a,6a,6b,7,8,8a-dodecahydro-3a,6b,8a-trihydroxy-2a-(hydroxymethyl)-1,1,5,7-tetramethyl-, (1a $\alpha, 1 \mathrm{~b} \beta, 1 \mathrm{c} \beta, 2 \mathrm{a} \beta, 3 \mathrm{a} \beta, 6 \mathrm{a} \alpha, 6 \mathrm{~b} \alpha, 7 \alpha, 8 \beta, 8 \mathrm{a} \alpha)-; \quad \mathrm{y}:$ Hexadecanoic acid, 1a,2,5,5a,6,9,10, 10a-octahydro-5,5a-dihydroxy-4-(hydroxymethyl)-1,1,7,9-tetramethyl-11-oxo-1H-2,8a-methanocyclopenta[a]cyclopropa[e]cyclodecen-6-yl ester, [1aR-(1a $\alpha, 2 \alpha, 5 \beta, 5 \mathrm{a} \beta, 6 \beta, 8 \mathrm{a} \alpha, 9 \alpha, 10 \mathrm{a} \alpha)]$-; z: Cyclopropanebutanoic acid, 2-[[2-[[2-[(2-pentylcyclopropyl)methyl]cyclopropyl]methyl] cyclopropyl]methyl]-, methyl ester.

(p)

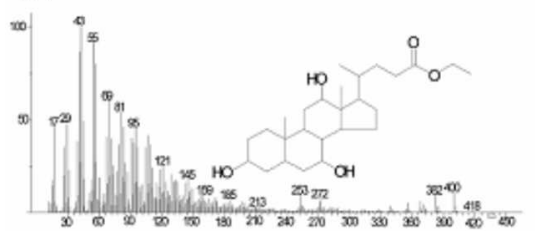

(q)

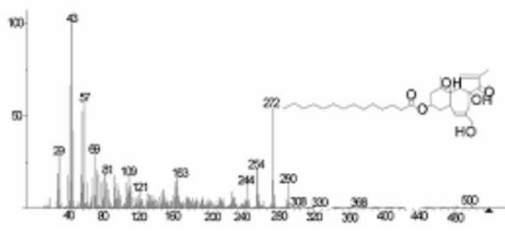

(r)

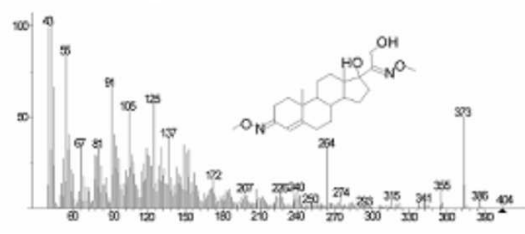

Fig. 1b. Pbhytochemical constitutents of defatted oven-dried (p) and sun-dried ( $\mathrm{q}$ and $\mathrm{r}$ ) B. sapida aril flour as determined using GC-MS analysis. Note: p: Ethyl iso-allocholate; q: Tetradecanoic acid, 3,3a,4,6a,7,8,9,10,10a,10b-decahydro-3a,10a-dihydroxy-5-(hydroxymethyl)2,10-dimethyl-3-oxobenz[e]azulen-8-yl ester, [3aR-(3a $\alpha, 6 a \alpha, 8 \alpha, 10 \beta, 10 \mathrm{a} \beta, 10 \mathrm{~b} \beta)]$-; r: Pregn-4-ene-3,20-dione, 17,21-dihydroxy-, bis(Omethyloxime).

followed by Turkey's multiple comparisons. Confidence value was set at $95 \%$.

\section{Results}

\subsection{Proximate composition}

In terms of the effect of the drying method on crude protein level, the oven-dried flour had significantly $(p>0.05)$ lower protein content compared to the sun-dried flour. However, considering the impact of defatting on B. sapida aril, the defatted flour at both drying instances had significantly $(p>0.05)$ higher crude protein content compared to the flour. The oven-dried aril flour also contained significantly $(p>0.05)$ lower fat compared to the sun-dried aril flour. The amount of crude fibre obtained in the defatted flours (for both oven-dried and sun-dried) was significantly $(p>0.05)$ higher compared to the fresh oven-dried aril flour (Tab. 1).

\subsection{Phytochemicals composition}

GC-MS analysis of the fresh B. sapida aril revealed the presence of pregn-4-ene-3,20-dione, 17,21-dihydroxy-, bis $(\mathrm{O}$ methyloxime) and 4H-Cyclopropa[5',6']benz[1',2':7,8]azuleno[5,6-b]oxiren-4-one, 8-(acetyloxy)-

1,1a, 1b, 1c,2a,3,3a,6a,6b, 7,8,8a-dodecahydro-3a,6b,8a-trihydroxy-2a-(hydroxymethyl)-1,1,5,7-tetramethyl-,

$(1 \mathrm{a} \alpha, 1 \mathrm{~b} \beta, 1 \mathrm{c} \beta, 2 \mathrm{a} \beta, 3 \mathrm{a} \beta, 6 \mathrm{a} \alpha, 6 \mathrm{~b} \alpha, 7 \alpha, 8 \beta, 8 \mathrm{a} \alpha)$ - in the ovendried flour while the sun-dried flour contained N-Methylpiperidin-2-yliden-3-morpholino-2-(4-chlorphenyl)-thioacrylamide, 4H-Cyclopropa[5',6']benz[1', 2':7,8]azuleno[5,6-b] oxiren-4-one, 8 (acetyloxy)1,1a,1b,1c,2a,3,3a,6a,6b,7,8,8adodecahydro-3a,6b,8a-trihydroxy-2a-(hydroxymethyl)-

1,1,5,7-tetramethyl-, $(1 \mathrm{a} \alpha, 1 \mathrm{~b} \beta, 1 \mathrm{c} \beta, 2 \mathrm{a} \beta, 3 \mathrm{a} \beta, 6 \mathrm{a} \alpha, 6 \mathrm{~b} \alpha, 7 \alpha, 8 \beta$, $8 \mathrm{a} \alpha)$-, Hexadecanoic acid, 1a,2,5,5a,6,9, 10,10a-octahydro5,5a-dihydroxy-4-(hydroxymethyl)-1,1,7,9-tetramethyl-11oxo-1H-2,8a-methanocyclopenta[a]cyclopropa[e]cyclodecen6-yl ester, [1aR- $(1 \mathrm{a} \alpha, 2 \alpha, 5 \beta, 5 \mathrm{a} \beta, 6 \beta, 8 \mathrm{a} \alpha, 9 \alpha, 10 \mathrm{a} \alpha)]-$ and cyclo- 
(a)

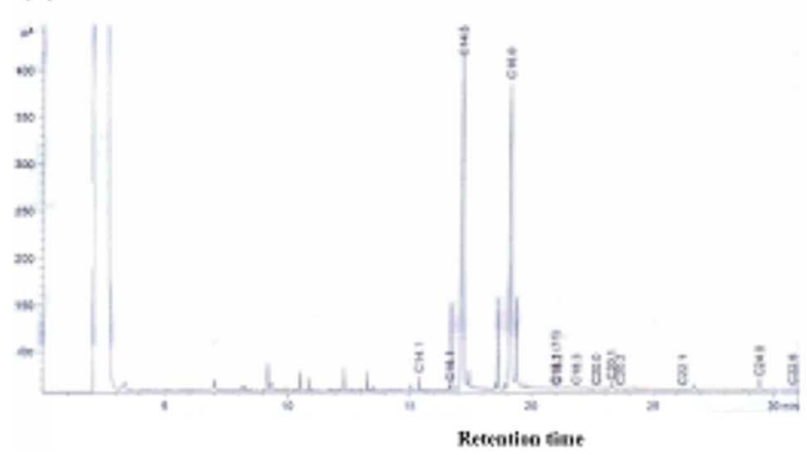

(b)

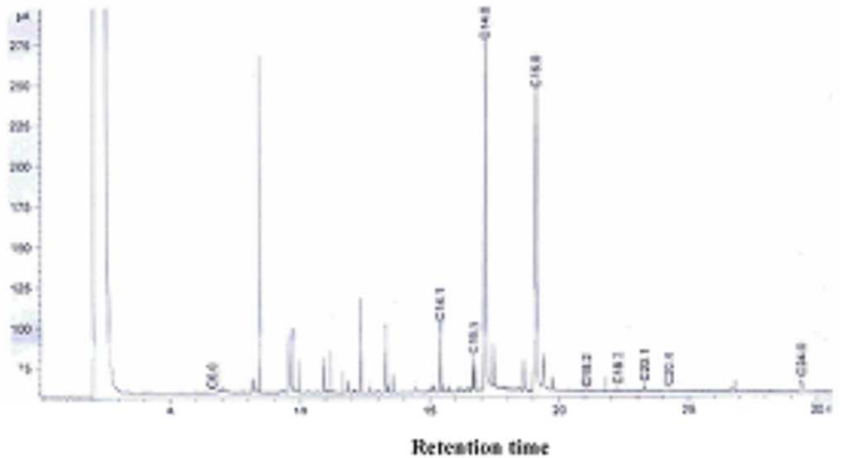

Fig. 2. Fatty acid composition of (a) oven-dried and (b) sun-dried B. sapida aril oil.

propanebutanoic acid, 2-[[2-[[2-[(2-pentylcyclopropyl)methyl] cyclopropyl]methyl]cyclopropyl]methyl]-, methyl ester. 4HCyclopropa[5',6']benz[1',2':7,8]azuleno[5,6-b]oxiren-4one,8-(acetyloxy)-1,1a,1b,1c,2a,3,3a,6a,6b,7,8,8a-dodecahydro-3a,6b,8a-trihydroxy-2a-(hydroxymethyl)-1,1,5,7-tetramethyl-, $(1 \mathrm{a} \alpha, 1 \mathrm{~b} \beta, 1 \mathrm{c} \beta, 2 \mathrm{a} \beta, 3 \mathrm{a} \beta, 6 \mathrm{a} \alpha, 6 \mathrm{~b} \alpha, 7 \alpha, 8 \beta, 8 \mathrm{a} \alpha)$ - was observed as a common component in both fresh oven- and sun-dried B. sapida aril flour (Fig. 1a). The defatted B. sapida aril flour showed the presence of ethyl iso-allocholate in the ovendried sample while the sun-dried sample revealed the presence of tetradecanoic acid, 3,3a,4,6a,7,8,9,10,10a,10b-decahydro3a,10a-dihydroxy-5-(hydroxymethyl)-2,10-dimethyl-3-oxobenz[e]azulen-8-yl ester, [3aR-(3a $\alpha, 6 a \alpha, 8 \alpha, 10 \beta, 10 \mathrm{a} \beta, 10 \mathrm{~b} \beta)]-$ and pregn-4-ene-3, 20-dione, 17,21-dihydroxy-, bis (O-methyloxime) (Fig. 1b). These diverse chemicals belong to different chemical groups ranging from steroids, phytosterols, polyphenolics, terpenes, fatty esters, alkaloids etc. For instance, Ethyliso-allocholate is a triterpene; Pregn-4-ene-3,20-dione, 17,21-dihydroxy-, bis(O-methyloxime) is a steroid etc. The phytochemical components of the respective samples are indicated in Table 2.

\subsection{Oil yield and fatty acid composition}

The calculated yields of oil were 31.3 and $38.0 \%$ for the oven-dried and sun-dried B. sapida aril flours, respectively. Analysis of the fatty acid composition of the oven-dried B. sapida aril oil showed $64.60 \%$ saturated fatty acid, $33.95 \%$ monounsaturated fatty acid and $1.45 \%$ polyunsaturated fatty acid. The major saturated fatty acid component is palmitic acid $(22.51 \mathrm{mg} / \mathrm{L})$, myristic acid $(16.74 \mathrm{mg} / \mathrm{L})$ and lignoceric acid $(1.98 \mathrm{mg} / \mathrm{L})$ (Fig. 2a). Fatty acid profile of the sun-dried B. sapida oil showed $89.65 \%$ saturated fatty acid, $9.13 \%$ monounsaturated fatty acid, and $1.23 \%$ polyunsaturated fatty acid. The major saturated fatty acids are palmitic acid $(52.22 \mathrm{mg} / \mathrm{L})$, myristic acid $(37.71 \mathrm{mg} / \mathrm{L})$, lignoceric acid $(3.07 \mathrm{mg} / \mathrm{L})$, and arachidic acid $\left(1.80 \times 10^{-1} \mathrm{mg} / \mathrm{L}\right)$. The monounsaturated fatty acids present are myristoleic acid $(7.74 \mathrm{mg} / \mathrm{L})$, gondoic acid $(1.03 \mathrm{mg} / \mathrm{L})$, palmitoleic acid $\left(3.44 \times 10^{-1} \mathrm{mg} / \mathrm{L}\right)$, erucic acid $\left(2.41 \times 10^{-1} \mathrm{mg} / \mathrm{L}\right)$ and oleic acid $\left(1.28 \times 10^{-1} \mathrm{mg} / \mathrm{L}\right)$ while the following polyunsaturated acids were present docosahexaenoic acid $\left(7.67 \times 10^{-1} \mathrm{mg} / \mathrm{L}\right)$, linolenic acid $\left(1.79 \times 10^{-1} \mathrm{mg} / \mathrm{L}\right), 20: 2\left(1.74 \times 10^{-1} \mathrm{mg} / \mathrm{L}\right)$ and linoleic acid $\left(1.55 \times 10^{-1} \mathrm{mg} / \mathrm{L}\right)$ (Fig. $\left.2 \mathrm{~b}\right)$.

\subsection{Physicochemical characteristics}

The physicochemical characteristics of the oven-dried and sun-dried B. sapida aril oil were similar except for the free fatty acid and total phenolic contents that were significantly $(p>0.05)$ lower in the oven-dried oil sample compared to the sun-dried oil sample (Tab. 3). The two oil samples were yellow in colour with refractive index of $1.21 \pm 0.02$ and $1.23 \pm 0.02$ for oven-dried and sun-dried B. sapida oils respectively.

\subsection{Antioxidant activity}

Both the sun-dried and oven-dried aril oil displayed significant DPPH scavenging activity (Fig. 3a), lipid peroxide inhibitory activity (Fig. 3b) and nitric oxide scavenging activity (Fig. $3 c$ ). The oven-dried aril oil showed a lower significant $(p<0.05)$ DPPH scavenging and nitric oxide inhibitory activities compared to the sun-dried aril oil. The scavenging effects on both DPPH and nitric oxide radical were dose-dependent. The sun-dried aril oil and oven-dried aril oil displayed similar lipid peroxide scavenging activity especially at higher concentration (Fig. 3b). Overall, vitamin C demonstrated superior scavenging potential against $\mathrm{DPPH}$, nitric oxide and lipid peroxide radicals compared to both oven-dried aril oil and sun-dried aril oil.

\section{Discussion}

The study on the composition of plants and plant products forms the basis for successful technological processing and applications of such plants (Saenz, 2000). The previous study on the proximate composition analyses of B. sapida arils from Toukountouna (Northwest Benin) showed that it contains $46 \%$ of crude fat, $47 \%$ of crude fibers and $3 \%$ of crude proteins (Dossou et al., 2004). The analysis of raw B. sapida arils from Mexico revealed $57.6 \%$ of moisture, $8.8 \%$ of crude protein, $18.8 \%$ of crude fat, $3.5 \%$ of crude fiber, $9.6 \%$ of total carbohydrates and $1.9 \%$ of ash (Morton, 1987). The crude protein values as reported for both oven-dried and sun-dried $B$. sapida flour in this study were higher than that reported by 
O.M. Oluba et al:: OCL 2019, 28, 17

Table 2. GC-MS data analysis of the phytochemical components of both fresh and defatted oven-dried and sun-dried B. sapida aril.

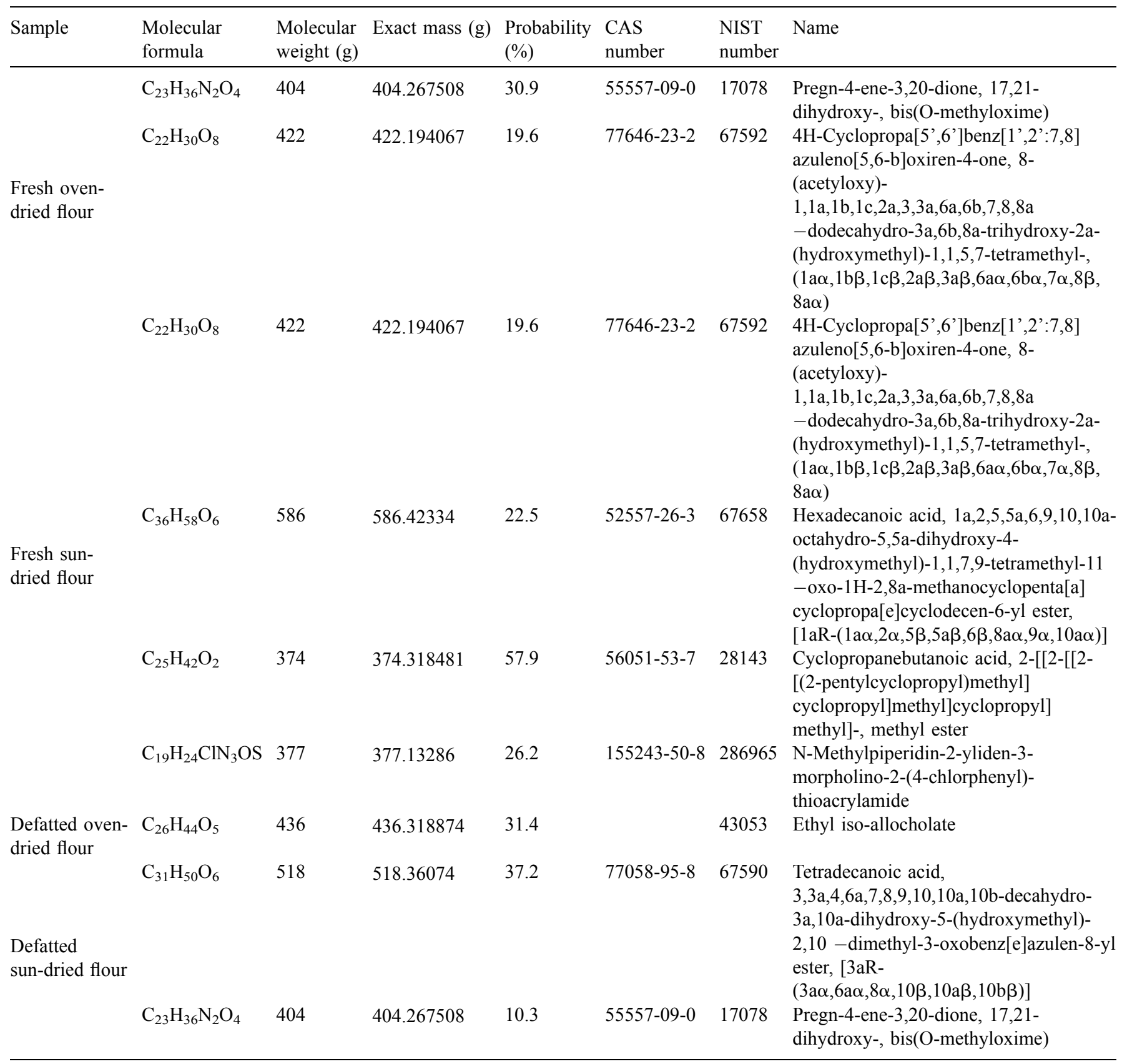

Dossou et al. (2004) and Morton (1987). In the same vein, results from the present study gave a crude fat level of $38.0 \%$ (for sun-dried flour) which was lower than the reported values by Dossou et al. (2004) and Morton (1987). This goes to show that the proximate composition of B. sapida flour could possibly vary from place to place. In addition, the present study demonstrated that the sun-dried B. sapida flour had considerably higher contents of protein and oil compared to oven- dried flour. Thus, in addition to the influence of geographical location in determining the percentage crude protein and fat in B. sapida flour, the choice of drying method also plays a significant role. Judging by results of this study, sun drying might be the preferred drying method of choice in obtaining higher protein and oil quantities from B. sapida flour. Defatting has been shown to improve the nutritional and functional attributes of oilseed flour (Akinyede and Amoo, 2009; Ndie et al., 2010). A report by Ndie et al. (2010) showed that defatted African walnut flour had higher protein content compared with the non-defatted flour. Results from this study showed that the crude protein contents of B. sapida aril flour were significantly increased after defatting. The crude protein content obtained for the defatted oven-dried and sun-dried B. sapida aril flours in this study compared favorably with that of many known legume flours, including cowpea $(24.1 \%)$, 
Table 3. Physicochemical characteristics of oven-dried and sundried B. sapida aril oil.

\begin{tabular}{lrr}
\hline Physicochemical parameter & \multicolumn{1}{l}{ ODAO } & \multicolumn{1}{c}{ SDAO } \\
\hline Colour & \multicolumn{1}{l}{ Yellow } & \multicolumn{1}{l}{ Yellow } \\
Refractive index & $1.21 \pm 0.02^{\mathrm{a}}$ & $1.23 \pm 0.02^{\mathrm{a}}$ \\
Specific gravity $\left(\mathrm{gL}^{-1}\right)$ & $0.91 \pm 0.02^{\mathrm{a}}$ & $0.90 \pm 0.01^{\mathrm{a}}$ \\
Peroxide value $\left(\mathrm{mg} \mathrm{reactive}_{2} \mathrm{~g}^{-1}\right)$ & $9.55 \pm 0.35^{\mathrm{a}}$ & $9.83 \pm 0.30^{\mathrm{a}}$ \\
Acid value $\left(\mathrm{mgKOHg}^{-1}\right)$ & $3.31 \pm 0.15^{\mathrm{a}}$ & $3.57 \pm 0.19^{\mathrm{a}}$ \\
Saponification value $\left(\mathrm{mgKOHg}^{-1}\right)$ & $191.50 \pm 7.23^{\mathrm{a}}$ & $196.35 \pm 5.32^{\mathrm{a}}$ \\
Iodine value $\left(\mathrm{mgI}_{2} \mathrm{~g}^{-1}\right)$ & $90.33 \pm 3.33^{\mathrm{a}}$ & $92.39 \pm 2.80^{\mathrm{a}}$ \\
Free fatty acid $(\%)$ & $0.21 \pm 0.01^{\mathrm{a}}$ & $0.35 \pm 0.00^{\mathrm{b}}$ \\
Total phenolic content $\left(\mathrm{mgGAEg}^{-1}\right)$ & $2.57 \pm 0.35^{\mathrm{a}}$ & $3.86 \pm 0.30^{\mathrm{b}}$ \\
\hline
\end{tabular}

Results are means \pm SD of three determinations. Values in the same row carrying different alphabets are significant $(p>0.05)$. Note: SDAO: sun-dried aril oil; ODAO: oven-dried aril oil; vit $C$ : vitamin C; GAE: gallic acid equivalent.

egusi melon (23.4\%), pigeon pea (19.9-24.0\%), and chicken pea (23.7\%) (Ojieh et al., 2007; Maninder et al., 2007; Anderson-Foster et al., 2012; Sreerama et al., 2012). The crude protein content of defatted B. sapida aril flour as reported in the present study is sufficient to meet the minimum dietary protein recommendation of the Food and Agriculture Organization (FAO/WHO, 2002).

Phytochemicals also referred to as plant secondary metabolites play significant roles in the free radical scavenging activities of plants and animals. The antioxidant properties of plants secondary metabolites are attributed to the activity of the phytochemicals they contain (Saxena et al., 2013; Lawal et al., 2018). The GC-MS fingerprints of both fresh and defatted $B$. sapida aril flour revealed the presence diverse phytochemicals including triterpenes, sesquiterpenes, steroids, quinones, alkaloids, polyphenols, glycosides and phytosterols in accordance with previous studies by Antwi et al. (2009), Onuekwusi et al. (2014), Balogun and Fetuga (1988). Pregn-4-ene-3,20-dione, 17,21-dihydroxy-, bis(O-methyloxime) has been reported to exhibit anti-inflammatory activity as well as been used in hormone replacement therapy (Hameed et al., 2018), Tetradecanoic acid, 3,3a,4,6a,7,8,9,10,10a,10b-decahydro3a,10a-dihydroxy-5-(hydroxymethyl)-2,10 -dimethyl-3-oxobenz[e]azulen-8-yl ester, [3aR-(3a $\alpha, 6 a \alpha, 8 \alpha, 10 \beta, 10 a \beta, 10 b \beta)$ ] has also been documented to show anti-inflammatory activity (Mohammed et al., 2016). Cyclopropanebutanoic acid, 2-[[2[[2-[(2-pentylcyclopropyl) methyl]cyclopropyl]methyl]cyclopropyl]methyl]-, methyl ester identified in the methanolic leaf extract of Cinnamomum iners was demonstrated to show strong antioxidant activity against reactive oxygen species (Udayaprakash et al., 2015). According to a report by Malathi and Ramaiah (2017), Ethyl iso-allocholate isolated from rice was demonstrated to exhibit antimicrobial acitivity against E. coli through the inhibition of dihydropteroate synthase.

Phenolic compounds, due to their electron releasing and hydrogen donating potentials, are responsible for the antioxidant activity of edible fruits and vegetables. The result obtained from the phytochemical screening of both fresh and defatted B. sapida aril flour showed the presence of phenolic compounds. Polyphenols, carotenoids and nitrogen containing (a)

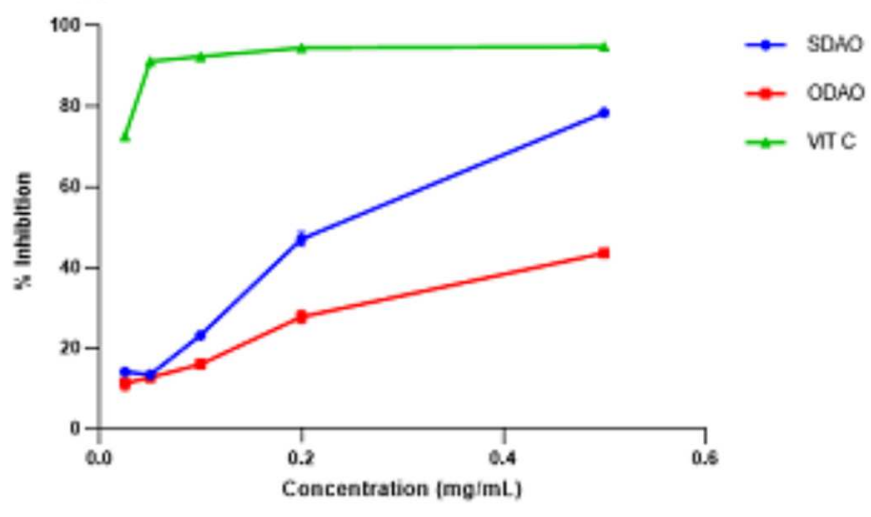

(b)

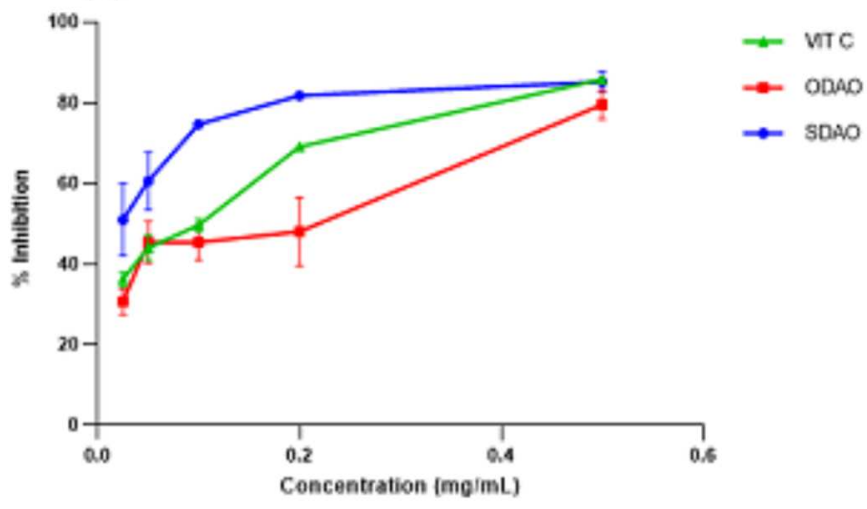

(c)

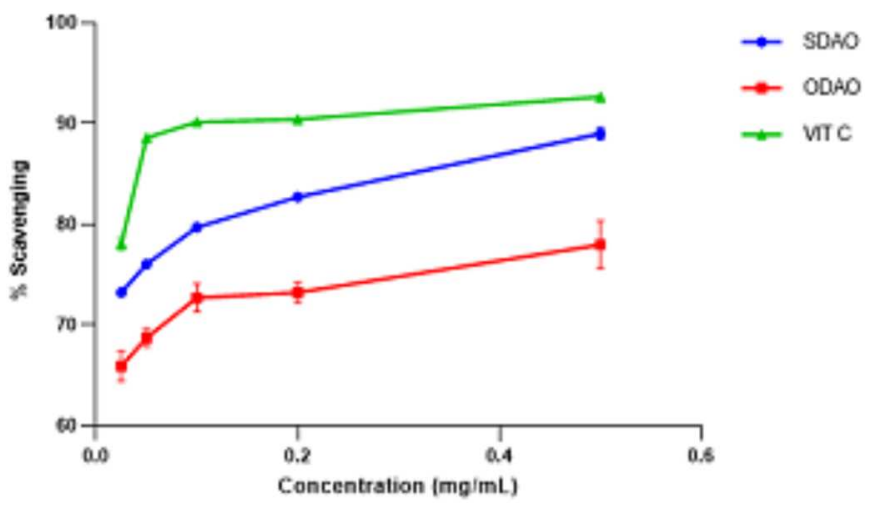

Fig. 3. DPPH scavenging activity (a) lipid peroxide inhibitory activity (b) and nitric oxide scavenging activity (c) of sun-dried and oven-dried B. sapida aril oil in comparison to vitamin C. Results are means \pm SD of three determinations. Note: SDAO: sun-dried aril oil; ODAO: oven-dried aril oil; vit $\mathrm{C}$ : vitamin $\mathrm{C}$.

compounds are classical examples of substances with antioxidant activities (Asiamah 2018; Musa et al., 2019). The high level of unsaturation in phenolic compounds makes them the preferred oxidation substrates for free radicals thus protecting intracellular molecules against oxidation. The phenolics component of B. sapida aril could thus account for its ability to scavenge free radicals in DPPH, nitric oxide and lipid peroxides as demonstrated in this study. In addition, the oven-dried and sun-dried aril oils contained as much as 
35.40 and $10.36 \%$ unsaturated fatty acids, respectively, which could serve as potential electron donors. Data from this study showed that the sun-dried B. sapida flour showed the presence of a more diverse range of phenolic compounds compared to the oven-dried flour. However, oil obtained from the ovendried flour showed a higher degree of unsaturation in terms of its fatty acid content than oil from the sun-dried flour. These observations could naturally translate to the sun-dried $B$. sapida oil exhibiting higher antioxidant ability than oil from the oven-dried B. sapida flour as was observed in the present study. The fatty acid profiles obtained from both ovendried and sun-dried B. sapida aril oil in the study identified palmitic acid as the major fatty acids. This is in agreement with the report of Odutuga et al. (1992) who had earlier shown that palmitic acid was the major fatty acid in B. sapida aril from Jamaica. However, other studies have shown that the major fatty acid in B. sapida aril is oleic acid (Tsado et al., 2018; Grande-Tovar et al., 2019). The differences in geographic location as well as processing methods could account for the different results.

In agreement with previous reports the oil obtained from both oven-dried and sun-dried B. sapida aril in this study is yellow in colour (Djenontin et al., 2009). The refractive index of 1.21 obtained for oven-dried B. sapida oil in this study is low compared to the value (1.46) obtained for B. sapida aril from Niger state, Nigeria. Refractive index of oil has been established to be a good predictor of oil susceptibility to rancidity. Oils with low refractive indices are less prone to oxidative rancidity (Godswill et al., 2018). Data on specific gravity obtained in the present study indicated that $B$. sapida aril oil is less dense compared to water. Oils generally have specific gravity of less than one. Reports from a study have demonstrated that $B$. sapida aril oil is less dense than oils from canola, cottonseed, and sesame (Dossou, 2014). The iodine values obtained for both sun-dried and oven-dried B. sapida aril in this study is similar to the reported value for palm oil but lower than that of groundnut oil, soybean oil and egusi melon (Oluba et al., 2008). The low iodine value reported for $B$. sapida aril oil in this study shows that it's a non-drying oil. The iodine value of oils gives a measure of their degree of unsaturation as well as their susceptibility to oxidative rancidity (Oyeleke et al., 2013; Adepoju et al., 2013). The acid values of 3.31 and $3.57 \mathrm{mgKOHg}^{-1}$ obtained for ovendried and sun-dried B. sapida aril oil, respectively in this study is low compared to the reported value for corn oil and peanut oil which are majorly utilized for pharmaceutical products. Thus, B. sapida aril oil could find possible application in the pharmaceutical industries. Its low acid value also showes that it is safe for consumption (Howele et al., 2010). The saponification values of oven-dried and sun-dried B. sapida aril oil obtained in this study compare relatively to that of most plant oils used in soap making (Oluba et al., 2008; AndersonFoster et al., 2012). This justified its suitability in soap making in countries like Nigeria and Benin (Ekué et al., 2010). Overall, the physicochemical characteristics results obtained for both oven-dried and sun-dried B. sapida aril oil in this study is higher than the values reported by Aloko et al. (2017).

The higher total phenolic content of the oil sample obtained from sun-dried B. sapida flour could possibly account for the observed higher capacity of the oils to scavenge DPPH radical when compared to oil from the oven-dried B. sapida flour.
Phenolics have established free radical scavenging activity hence capable of minimizing oxidative degradation of biomolecules (Kang et al., 2005; Amoateng et al., 2010). According to the recommendation of Scalbert and Williamson (2000) the consumption of $1000 \mathrm{mgGAE} /$ day of antioxidants is desirable thus the daily intake of $100 \mathrm{~g}$ of B. sapida oil is sufficient to meet this nutritional requirement. The stem back extract of B. sapida was recently demonstrated to show DPPH scavenging as well as iron chelating activities (Ojo et al., 2018). According to Oloyede et al. (2013), B. sapida aril polyphenolics was demonstrated to scavenge and detoxify free radicals thus impeding lipid and protein oxidation. In addition, the ethyl acetate extracts of B. sapida pod and seed were demonstrated to exhibit strong DPPH antioxidant activities (Parkinson, 2007).

\section{Conclusion}

Data obtained from this study showed that the chemical composition of Blighia sapida aril is greatly influenced both by geographical location and preservation method. Our data showed that sun-dried B. sapida flour contained higher crude protein and crude fat than oven-dried flour. In addition, the sun-dried B. sapida aril flour contained more diverse phytochemicals compared to the oven-dried aril flour. More so, oil from the sun-dried aril had significantly higher total phenolics content and thus displayed better antioxidant activity compared to the oven-dried aril oil. However, in vitro antioxidant assays do not always translate to antioxidant properties, therefore, to further ascertain this claim, in vivo studies are necessary. Therefore, the method of choice for drying will be greatly influenced by the intended application of either the flour or the oil. Based on results obtained from this study, sun-drying is recommended for both nutritional purposes and health-promoting usage such as antioxidant, over oven-drying.

\section{Abbreviations}

$\begin{array}{ll}\text { BSAF } & \text { Blighia sapida aril flour } \\ \text { ODAO } & \text { Oven dried aril oil } \\ \text { SDAO } & \text { Sun-dried aril oil } \\ \text { GC-MS } & \text { Gas chromatography-mass spectrometry } \\ \text { DPPH } & \text { 2,2-diphenyl-1-picrylhydrazyl } \\ \text { NO } & \text { Nitric oxide }\end{array}$

Conflicts of interest. The authors declare no conflicts of interest.

\section{References}

Adarkwa-Yiadom K. 2018. A preliminary study of the antiproliferative properties of crude blighia sapida seeds extracts on lung, prostate, skin, leukemic cancers and normal human liver cells. Dissertation, Kwame Nkrumah University of Science and Technology Kumasi, Ghana.

Adeduntan SA, Olawale AE, Oyerinde OV. 2016. Utilization of Blighia sapida (KD Koenig) in Rainforest and Savanna Zones of South-West, Nigeria. Appl Trop Agric 21: 166-73. 
Adepoju AJ, Abdul-Hammed M, Esan AO, Bello MO. 2013. Variation in the chemical parameters of oil extracted from arils of Blighia sapida (ackee) with the degree of fruit ripeness. Int $J$ Basic Appl Sci 2: 109-114.

Akintayo ET, Adebayo EA, Arogunde LA. 2002. Assessment of dietary exposure to the natural toxin hypoglycin in ackee (Blighia sapida) by Jamaicans. Food Res Int 37: 833-838.

Akinyede AI, Amoo IA. 2009. Chemical and functional properties of full fat and defatted Cassia fistula seed flours. Pak J Nutr 8: 765769.

Aloko S, Azubuike CP, Coker HA. 2017. Physicochemical properties and lubricant potentials of Blighia sapida Sapindaceaeae seed oil in solid dosage formulations. Trop J Pharm Res 16: 305-311.

Amoateng P, Kumah DB, Koffuor GA. 2010. Antioxidant and free radical scavenging properties of an aqueous ripe fruit extract of Borassus aethiopum. West Afr J Pharmacol Drug Res 26: 8-14.

Anderson-Foster EN, Adebayo AS, Justiz-Smith N, Indies W. 2012. Physico-chemical properties of Blighia sapida (ackee) oil extract and its potential application as emulsion base. Afr J Pharm Pharmacol 6: 200-210.

Antwi S, Martey ON, Donkor K, Okine LK. 2009. Anti-diarrhoeal activity of Blighia sapida (Sapindaceae) in rats and mice. $J$ Pharmacol Toxicol 4(3):117-5.

Arina MI, Harisun Y. 2019. Effect of extraction temperatures on tannin content and antioxidant activity of Quercus infectoria (Manjakani). Biocat Agric Biotechnol 19: 101104.

Asadi N, Bahmani M, Kheradmand A, Rafieian-Kopaei M. 2017. The impact of oxidative stress on testicular function and the role of antioxidants in improving it: a review. J Clin Diagn Res 11(5): IE01.

Asiamah GS. 2018. Antinutrient contents of ackee (Blighia sapida) arils as influenced by some processing methods. Ghana: Kwame Nkrumah University of Science and Technology Kumasi.

Association of Official Analytical Chemists. 2005. Official methods of analysis, 16th ed. Washington, DC: Association of Official Analytical Chemists.

Ayanwale BA, Ocheme OB, Oloyede OO. 2007. The effect of sundrying and oven-drying on the nutritive value of meat pieces in hot humid environment. Pak J Nutr 6(4): 370-374.

Balogun AM, Fetuga BL. 1988. Tannin, phytin and oxalate contents of some wild under-utilized crop-seeds in Nigeria. Food Chem 30 (1): 37-43.

Bersuder P, Hole M, Smith G. 1998. Antioxidants from a heated histidine-glucose model system. I: Investigation of the antioxidant role of histidine and isolation of antioxidants by highperformance liquid chromatography. J Am Oil Chem Soc 75(2): 181-187.

Blake OA, Bennink MR, Jackson JC. 2006. Ackee (Blighia sapida) hypoglycin A toxicity: Dose response assessment in laboratory rats. Food Chem Toxicol 44(2): 207-213.

Bowen-Forbes CS, Minott DA. 2011. Tracking hypoglycins A and B over different maturity stages: implications for detoxification of ackee (Blighia sapida KD Koenig) fruits. J Agric Food Chem 59: 3869-3875.

Brown M, Bates RP, McGowan C, Cornell JA. 1991. Influence of fruit maturity on the hypoglycin A level in ackee (Blighia sapida) $1 . J$ Food Safety 12(2): 167-77.

Dileesh S, Adithya M, Sankar A, Peter CV. 2013. Determination of saponification, acid and ester values; percentage of free fatty acids and glycerol in some selected edible oils: Calculation of concentration of lye needed to prepare soap from these oils. UG Scholars.
Djenontin ST, Wotto VD, Lozano P, Pioch D, Sohounhloué DKC. 2009. Characterisation of Blighia sapida (Sapindaceae) seed oil and defatted cake from Benin. Nat Prod Res (Former Nat Prod Lett) 23: 549-560.

Dossou VM. 2014. Physicochemical and functional properties of different ackee (Blighia sapida) aril flours. Dissertation, Kwame Nkrumah University of Technology Kumasi, Ghana.

Dossou MK, Codjia JT, Biaou G. 2004. Rôle de la ressource forestière Blighia sapida (ackee ou faux acajou) dans l'économie des ménages du Nord-Ouest du Bénin. Bulletin de la Recherche Agronomique du Bénin 46: 33-41.

Ekué MR, Sinsin B, Eyog-Matig O, Finkeldey R. 2010. Uses, traditional management, perception of variation and preferences in ackee ( KD Koenig) fruit traits in Benin: implications for domestication and conservation. J Ethnobiol Ethnomed 6: 12.

Ekué MR, Gailing O, Vornam B, Finkeldey R. 2011. Assessment of the domestication state of ackee (Blighia sapida KD Koenig) in Benin based on AFLP and microsatellite markers. Conserv Genet 12: $475-489$.

Food and Agriculture Organization (FAO)/World HealthOrganization (WHO). 2002. Human Vitamin and Mineral Requirements. Rome: FAO; Report of a Joint FAO/WHO Expert Consultation.

Godswill AC, Amagwula IO, Victory IS, Gonzaga AI. 2018. Effects of repeated deep frying on refractive index and peroxide value of selected vegetable oils. Int J Adv Acad Res 4(4): 106-119.

Golden KD, Kean EA, Terry SI. 1984. Jamaican vomiting sickness: a study of two adult cases. Clin Chim Acta 142: 293-298.

Grande-Tovar CD, Johannes DO, Puerta LF, Rodriguez GC, Sacchetti G, Paparella A, et al. 2019. Bioactive micro-constituents of ackee arilli (Blighia sapida KD Koenig). Anais da Academia Brasileira de Ciências 91(3): e20180140.

Gul K, Singh AK, Jabeen R. 2016. Nutraceuticals and functional foods: The foods for the future world. Crit Rev Food Sci Nutr 56: 2617-2627.

Hameed RH, Mohammed GJ, Hameed IH. 2018. Matricaria chamonbmilla: Bioactive compounds of methanolic fruit extract using GC-MS and FTIR techniques and determination of its antimicrobial properties. Indian J Public Health Res Dev 9 (3):223-8.

Hoba AM, Digbeu YD, Binaté S, Dué EA, Kouamé LP. 2018. Fatty Acids and physicochemical compositions of dried and roasted Blighia sapida arils oils (Ackee Apple) from Côte d'Ivoire. Asian $J$ Res Biochem, 1-7.

Howele O, Bobele N, Theodor D, Seraphi KC. 2010. Nutritional composition studies of sun dried Blighia sapida (K. Koenig) aril from Cote d'Ivoire. J Appl Biosci 32: 1989-1994.

Kang H, Mansel RE, Jiang WG. 2005. Genetic manipulation of stromal cell-derived factor-1 attests the pivotal role of the autocrine SDF-1-CXCR4 pathway in the aggressiveness of breast cancer cells. Int $J$ Oncol 26: 515-1434.

Kardash E, Tur YI. 2005. Acid value determination in vegetable oils by indirect titration in aqueous-alcohol media. Croatica Chem Acta 78: 99-103.

Karthikeyan M, Renganathan S, Baskar G, Nambirajan S. 2017. Extraction of non-edible oil from Catharanthus roseus seeds and kinetics on oil extraction. Energy Sources Part A: Recovery Utiliz Environ Effects 39(16): 1746-53.

Lawal RT, Oyeleke GO, Ishola AD, Akinsuroju MO. 2018. Determination of physiochemical properties and lactic acid bacteria presence in ackee (Blighia sapida) Fruit. Int $J$ Environ Agric Biotechnol 3: 1079-1082. 
Li SG, Zhang H, Xue WT. 2007. A novel method for the determination of acid value of vegetable oils. Eur J Lipid Sci Technol 109: 1088-1094.

Manchester KL. 1974. Biochemistry of hypogylcin. FEBS Lett 40: S133.

Makhija IK, Aswatha Ram HN, Shreedhara CS, Vijay Kumar S, Devkar R. 2011. In vitro antioxidant studies of Sitopaladi Churna, a poluherbal Ayurvedic formulation. Free Radic Antioxid 1: $37-$ 41.

Malathi K, Ramaiah S. 2017. Ethyl iso-allocholate from a medicinal rice Karungkavuni inhibits dihydropteroate synthase in Escherichia coli: A molecular docking and dynamics study. Indian $J$ Pharm Sci 78(6): 780-8.

Maninder K, Kawaljit SS, Narpinder S. 2007. Comparative study of the functional, thermal and pasting properties of the flours from different field pea (Pisum sativum L.) and pigeon pea (Cajanus cajan L.) cultivars. Food Chem 104: 259-267.

Morton J. (1987) Akee. In: Fruits of warm climates. Miami, Florida, pp. 269-271.

Mohammed GJ, Omran AM, Hussein HM. 2016. Antibacterial and phytochemical analysis of Piper nigrum using gas chromatography-mass spectrum and fourier-transform infrared spectroscopy. Int J Pharmacog Phytochem Res 8(6): 977-96.

Musa DA, Dim-Gbereva L, Ogbiko C, Nwodo OF. 2019. Phytochemical and in vitro anti-typhoid properties of leaf, stem and root extracts of Ficus capensis (Moraceae). J Pharm Bioresour 16: 165-172.

Ndie EC, Nnamani CV, Oselebe HO. 2010. Some physicochemical characteristics of defatted flours derived from African walnut (Tetracarpidium conoforum): An underutilized legume. Pak J Nutr 9: 909-911.

Odutuga AA, Asemota HN, Musac I, Golden KD, Kean EA. 1992. Fatty acid composition of arilli from ackee fruit (Blighia sapida L). Jamaican J Sci Technol 3: 30-32.

Ojieh GC, Oluba OM, Ogunlowo YR, Adebisi KE, Eidangbe GO, Orole RT. 2007. Compositional studies on Citrullus lanatus (egusi melon) seed. Intern J Nutr Wellness 6: 1-5.

Ojo OA, Ajiboye BO, Imiere OD, Adeyonu O, Olayide I, Fadaka A. 2018. Antioxidative properties of Blighia sapida K.D. Koenig stem bark extract and inhibitory effects on carbohydrate hydrolyzing enzymes associated with non-insulin dependent diabetesmellitus. Pharmacog $J$ 10: 376-383.

Okoh SO, Asekun OT, Familoni OB, Afolaya AJ. 2014. Antioxidant and free radical scavenging capacity of seed and shell essential oils extracted from Abrus precatorius (L). Antioxidants 3: 278287.

Oloyede HO, Ajiboye TO, Komolafe YO, Salau AK. 2013. Polyphenolic extract of Blighia sapida arilli prevents
N-nitrosodiethylamine-mediated oxidative onslaught on microsomal protein, lipid and DNA. Food Biosci 1: 48-56.

Oluba OM, Ogunlowo YR, Ojieh GC, Adebisi KE, Eidangbe GO, Isiosio IO. 2008. Physicochemical properties and fatty acid composition of Citrullus lanatus (egusi melon) seed oil. J Biol Sci 8(4): 814-817.

Oluba OM, Akpor OB, Alabi OO, Shoyombo AJ, Adeyonu AG, Adebiyi FD. 2020. In vitro antioxidant properties and digestibility of chicken feather protein hydrolysates. Food Res 4(4): 10531059.

Onuekwusi EC, Akanya HO, Evans EC. 2014. Phytochemical constituents of seeds of ripe and unripe Blighia Sapida (K. Koenig) and physicochemical properties of the seed oil. Int $J$ Pharm Sci Invent 3(9): 31.

Oyeleke GO, Oyetade AO, Afolabi F, Adegoke BM. 2013. Nutrients, antinutrients and physicochemical compositions of Blighia sapida pulp and pulp oil (ackee apple). J Appl Chem 4(1): 5-8.

Parkinson A. 2007. Phytochemical Analysis of Ackee (Blighia sapida) Pods, 1st ed. New York: City University of New York.

Saenz C. 2000. Processing technologies: an alternative for cactus pear (Opuntia spp.) fruits and cladodes. J Arid Environ 46(3): 209225.

Saxena M, Saxena J, Nema R, Singh D, Gupta A. 2013. Phytochemistry of medicinal plants. $J$ Pharmacogn Phytochem 1(6): $168-182$.

Scalbert A, Williamson G. 2000. Dietary intake and bioavailability of polyphenols. J Nutr 130: 2073S-2085S.

Sreerama YN, Sashikala VB, Pratape VM, Singh V. 2012. Nutrients and antinutrients in cowpea and horse gram flours in comparison to chickpea flour: Evaluation of their flour functionality. Food Chem 131(2): 462-468.

Stalikas CD. 2007. Extraction, separation, and detection methods for phenolic acids and flavonoids. J Sep Sci 30(18): 3268-3295.

Strong FM, Kosh GH. 1974. Biochemistry laboratory manual, 2nd ed. Dubuque IA: VMC Publishers.

Tsado DB, Ndamitso MM, Ajai AI. 2018. Determination of Physicochemical Properties and Fatty Acid Profile of Oil Extract of Blighia sapida Fruit from Selected Areas in Niger State, Nigeria. Niger J Chem Res 23(1): 21-34.

Udayaprakash NK, Ranjithkumar M, Deepa S, Sripriya N, Al-Arfaj AA, Bhuvaneswari S. 2015. Antioxidant, free radical scavenging and GC-MS composition of Cinnamomum iners Reinw. ex Blume. Ind Crops Prod 69: 175-9.

Waterhouse AL. 2002. Determination of total phenolics. Curr Protocols Food Analyt Chem 6(1): I1-21.

Yildiz G, Wehling RL, Cuppett SL. 2003. Comparison of four analytical methods for the determination of peroxide value in oxidized soybean oils. J Am Oil Chem Soc 80(2): 103-107.

Cite this article as: Oluba OM, Mbamara D-FO, Akpor OB, Adebiyi FD, Alabi OO, Shoyombo A, Osemwegie OO. 2021. Effects of drying methods on compositional characterization and functional characteristics of Blighia sapida aril oil. OCL 28 : 17. 